\title{
The Relation between Parents' Child-Rearing Behavior and Their Socioeconomic Status in a Developing Country Context: A Case from West Bengal, India
}

\begin{abstract}
This study examines variation in parents' child-rearing behavior based on their socioeconomic status (SES) in the context of a developing country. The impact of different aspects of SES on the probability of practicing several child-rearing behaviors was examined individually based on a data of 1373 households in West Bengal, India. The study found that components of SES explain great shares of the variance in parents' child-rearing behaviors and the variation was bi-dimensional. There was variation between parental practices due to a change in SES, and also each practice was affected differently for each component of SES. Mother's level of education was found to play a consistent and most significant role in improving parent-child regular interaction.
\end{abstract}

Keywords: child-rearing behavior, socioeconomic status, mother's education, developing country

\section{Zusammenfassung}

Diese Studie untersucht die Variation im Erziehungsverhalten der Eltern in Abhängigkeit von ihrem sozioökonomischen Status (SES) im Kontext eines Entwicklungslandes. Der Einfluss verschiedener Aspekte des SES auf die Wahrscheinlichkeit, mehrere Erziehungsverhaltensweisen zu praktizieren, wurde individuell auf der Grundlage von Daten von 1373 Haushalten in Westbengalen, Indien, untersucht. Mit der Studie kann gezeigt werden, dass Komponenten des SES große Anteile der Varianz im Erziehungsverhalten der Eltern erklären und dass die Variation zweidimensional ist. Es gab Variationen zwischen den elterlichen Praktiken aufgrund einer Veränderung des SES, und auch jede Praxis war für jede Komponente des SES unterschiedlich betroffen. Es wurde festgestellt, dass das Bildungsniveau der Mutter eine konsistente und hoch signifikante Rolle bei der Verbesserung der regelmäßigen Eltern-Kind-Interaktion spielt.

Schlüsselworte: Erziehungsverhalten, sozioökonomischer Status, Bildung der Mutter, Entwicklungsland

\section{Introduction}

Parents are a very important source of children's development. They influence their children's development in many ways, and parental influence is great especially during early childhood. Substantial evidence shows that parents' involvement in child development can provide a positive outcome for children as it provides immediate structure to children's development (El Nokali, Bachman \& Votruba-Drzal, 2010; Bradley, 2002; Bradley \& Corwyn, 1999).

Parents' economic and psychological characteristics, their education goals, parenting style, and behavior are intertwined with the way children are stimulated at their home. From earlier research it is known that the way children grow up does have a strong influence on their later psychological and economic life outcomes (El Nokali et al., 2010). Children with parental support in learning and development face benefit in their educational attainment years later (Feinstein \& Duckworth, 2006). However, the effect of parents' involvement on child achievement is not always uniform across different socioeconomic groups. There is evidence that parenting behavior varies across different socioeconomic classes (Hoff, Brett \& Tardif, 2002; Sénéchal \& LeFevre, 2002), and that parents' beliefs are likely to be complex, heterogeneous and domain-specific (Tuli, 2013). Studies exploring parenting aspects in India show that childcare, adult beliefs and children's expressions were deeply intertwined with the circumstances in which families were living. Also, the cultural differences in childcare practices vary significantly from that of other Asian, and European or American parents (Chaudhary, 2013).

Because research exploring the variation in parental child-rearing behavior seems to be quite restricted to western societies, we apply the current theoretical and empirical background on the relation between parents' SES and parenting behavior in the case of India, as an example of a developing country. Based on these considerations, two research questions were formulated for the present study: Do different aspects of SES cause variation in parents' child-rearing behavior in the Indian context? Does the association between SES and child-rearing practices vary, depending on the type of practice 


\begin{tabular}{lccc}
\hline District & $\begin{array}{c}\text { Total Sample Size } \\
\text { (Households) }\end{array}$ & Rural & Urban \\
\hline Howrah & 473 & 235 & 238 \\
Murshidabad & 900 & 788 & 112 \\
Total & 1373 & 1023 & 350 \\
\hline
\end{tabular}

Tab. 1: Sampling Distribution across Districts and Areas, Source: Own presentation

and the components of SES? It is assumed that each of the components will affect parenting behavior differently and that assumptions from the current, western literature might not hold entirely true in the context of a developing country.

\section{Theoretical Background}

The physical and social setting in which the child lives, as well as culturally regulated customs of child-rearing are important components of child development (Super \& Harkness, 1986). Darling and Steinberg (1993) disentangled parenting in three different components: (a) the goal towards which socialization is directed, (b) the parenting style within which socialization occurs, and (c) the parental practice to help children reach the goal. Parenting practices include parents' behavior and interactions with their children - categorized as verbal interaction, direct control practices, and managerial control (Hoff et al., 2002). Later, Sigel and McGillicuddy-De Lisi (2002) added parental belief as a component of parenting. These different aspects of parenting are closely associated with socioeconomic status and "parents from different socioeconomic strata rear their children differently partly in response to the different circumstances in which they live and partly because they are themselves different sorts of people with different ways of interacting with the world" (ibid., p. 231). Educational, occupational, and financial factors all generate SES-related differences in child-rearing behavior, with educational factors carrying the highest share of variance (ibid.).

There is substantial evidence that both the amount and the nature of verbal interaction taking place between parents and children differ as functions of SES. E. g., higher-SES mothers address more speech to their children than do lower-SES mothers (Hoff-Ginsberg, 1998; Feiring \& Lewis, 1981). Also with respect to the content of verbal interaction, higher-SES children are provided with a greater variety of words, greater syntactic complexity, and a larger proportion of conversationeliciting questions (Hoff et al., 2002, Hoff-Ginsberg, 1998). Also with respect to direct control practices, lower SES mothers are found to be more controlling and restrictive (Budwig \&
Chaudary, 1996; Hart \& Risley, 1995), granted children less autonomy, were less equalitarian, less cooperative, compared to higher SES parents (Woodworth, Belsky \& Crnic, 1996). Regardless of different approaches to conceptualize parental practice, direct interaction with children is a central aspect of parenting which has been observed by a large body of research (cf. Hoff-Ginsberg \& Tardif, 1995). Furthermore, different components of SES bear different relations to parenting behavior and child outcomes (Hoff et al., 2002). SES is a multifaceted variable that signifies an individual's, a family's, and a group's position on a hierarchy according to its control over wealth, power, and social status (Mueller \& Parcel, 1981). The quality of home learning environment and child-rearing behavior are found to be relatively strongly correlated with parental income and education, social class, ethnic or cultural differences (Jonsson \& Erikson, 2000; Gutman \& Feinstein, 2007).

\section{Data and Methodology}

The study was conducted in West Bengal, located in the eastern part of India. The state West Bengal was purposefully chosen for practical reasons such as convenience in terms of finding the sample more accurately, and efficiency in terms of cost and time. Within the state, the sampling was divided into four stages: selection of districts, sub-districts, schools, and children in their households. At the first stage, all 19 districts of West Bengal were classified according to their literacy rate (Census of India, 2011). Then, one district was selected randomly from the above-average tier (Howrah district; adult literacy rate $83 \%$ ) and another from the below-average tier (Murshidabad district; adult literacy rate 67\%). At the second stage, two subdistricts (rural and urban) from each of the districts with the highest population were chosen. Finally, Howrah district includes the rural sub-district Domjur C.D. Block (7.3\% of total district population) and the urban sub-district Howrah Municipal Corporation (23.6\% of total district population). Likewise, in Murshidabad district, Berhampur C.D. Block (6.5\% of total district population) and Berhampur Municipality (5.3\% of total district population) were chosen. Distributing

\begin{tabular}{|c|c|c|c|c|c|}
\hline State/District & $\begin{array}{c}\text { Total Population } \\
\text { (in million) }\end{array}$ & Total Workers & Main Workers & $\begin{array}{c}\text { Marginal } \\
\text { Workers }^{\mathrm{a}}\end{array}$ & Non-Workers $^{\mathrm{a}}$ \\
\hline West Bengal & 91.3 & 38.1 & 28.1 & 9.9 & 61.9 \\
\hline Howrah & 4.8 & 37.5 & 30.9 & 6.7 & 62.5 \\
\hline Murshidabad & 7.1 & 36.5 & 28.5 & 8.0 & 63.5 \\
\hline
\end{tabular}




\begin{tabular}{|l|l|}
\hline & Yes \\
\hline Do you play with the child at home? & 91.4 \\
\hline Do you supervise the child's study/homework at home? & 82.8 \\
\hline Do you ask the child about his/her school experiences? & 68.1 \\
\hline Do you tell rhymes/stories to the child? & 50.3 \\
\hline Do you help the child managing time in literacy and non-literacy activities? & 44.3 \\
\hline
\end{tabular}

Tab. 3: Percentage of Self-disclosed Parenting Practices $(n=1373)$, Source: Own presentation

the sample into rural-urban habitation was due to the huge variation in socio-economic aspects based on whether parents live in rural or urban areas (Census of India, 2011) and evidence showing significant variation in childcare depending on rural-urban location (Atkinson, 1994). Table 1 provides the sample distribution across districts and rural-urban inhabitation. The unit of analysis for the study is the household having at least one child in Grade 1.

Descriptive statistics: Murshidabad district comprises $6 \%$ of the total area and $7.8 \%$ of the total population of West Bengal. Howrah district comprises about $1.6 \%$ of the total area with a population share of $5.3 \%$ of the state. The aggregated population of these two districts represents about $13 \%$ of the state's total population. Table 2 provides a comparison of districts with respect to the occupational pattern of the people. There is a considerable difference between districts with respect to the type of main and marginal worker. Whereas Murshidabad is dominated by agriculture workers, Howrah is led by non-agricultural workers mainly consisting of industrial labor and others. Instruments for child-rearing behavior: The primary focus of this study was on direct parent-child interaction in daily life, as this has been considered a central aspect of parenting (Hoff-Ginsberg \& Tardif, 1995). The second aim was to consider all three types of parenting practices, i.e. verbal interaction, direct control practices, and managerial control (Hoff et al., 2002). Child-rearing behavior was assessed with parents' self-disclosure on five items (see Table 3).

Socio-economic status (SES): SES is disentangled into economic status, educational status, and social status. The measures for economic status include information on monthly household expenditure (in Indian rupee), house type (concrete, semi-concrete, non-concrete), and house ownership (owned or rented). Parents' educational status was measured in the form of each parents' educational level: up to primary, above primary up to secondary, higher secondary or above. Social status was measured by the type of parents' occupation: self-employment, regular employment (having a stable job and worked at least 3 months in last 6 months), casual employment (worked less than 3 months in last 6 months). Descriptive statistics shows significant variation in SES based on whether parents practice certain child-rearing behavior. The percentage of practicing child-rearing behavior increases with greater household expenditure, higher level of education, and with relatively stable occupation of parents (see Appendix $1^{1}$ and Appendix $2^{1}$ ).

Control variables: We controlled for cultural background, family structure, and regional variation. To characterize households by social group and religion, dummy variables were used. Controls for household characteristics were family size,

\begin{tabular}{|c|c|c|}
\hline Model & Description & $\begin{array}{c}\text { Measures } \\
\text { (independent variables) }\end{array}$ \\
\hline Model 0 & Controls & See Appendix 3 \\
\hline Model 1 & Economic Status & $\begin{array}{l}\text { Monthly household expenditure (Indian Rupee) } \\
\text { Type of house } \\
\text { House ownership }\end{array}$ \\
\hline Model 2 & Educational Status & $\begin{array}{l}\text { Father's education } \\
\text { Mother's education }\end{array}$ \\
\hline Model 3 & Social Status & $\begin{array}{l}\text { Father's occupation } \\
\text { Mother's occupation }\end{array}$ \\
\hline Model 4 & $\begin{array}{l}\text { Economic, educational, and } \\
\text { social Status }\end{array}$ & Combination of Models 1, 2, and 3 \\
\hline
\end{tabular}

Tab. 4: Logistic Regression Models used for the Analyses, Source: own presentation 
number of children, presence of grandparents, parents' daily working hours. We also controlled for the child's health status and sex. District and rural/urban dummies were also included (see Appendix $3^{1}$ ).

Regression strategy: Logistic regression analyses were conducted with the five aspects of child-rearing behavior as dichotomous dependent variables. To see the influence of different socio-economic aspects on the likelihood of practicing a particular behavior, we run different models as described in Table 4. The McFadden curves for each of the dependent variables show the relative variation in parental behavior for each of the SES components measured in this study. The logistic regression coefficients provide direction of the effects of the SES components on child-rearing behavior.

\section{Results and Discussion}

Previous studies, conducted mostly in western context, found that practices like reading books or telling stories to children were the most widely practiced child-rearing behaviors among parents. On the contrary, this study found some deviation in practice of different child-rearing behaviors of parents in India. A considerably higher percentage of parents was found to play with children, supervise children's homework, rather than story-telling. This gives the initial impression that the set of parental practices performed by these parents seem to differ considerably from what has been found so far in western countries. Further analyses comprised of how much of the variation in these child-rearing behaviors is due to differences in SES, and if each of these behaviors is affected by SES in a similar fashion. Explained variance in logistic regression models: Overall, we find that aspects of SES, together with the controls, explain great shares of variance in parent's child-rearing behavior. While the control variables (Model 0) explain $15 \%$ to $27 \%$ of the variance (McFadden's $\mathrm{R}^{2}$ ), socio-economic aspects additionally contribute to a significant amount (see Table 5).

Economic status: Household expenditures, type of house and house ownership (Model 1) do not seem to play a very important role in parents' child-rearing behavior. Although the variation explained by economic status was significantly higher than what is explained by controls only, the difference in the explained variance is small. This especially applies to time management (McFadden's $\left.\mathrm{R}^{2}=0.28, \mathrm{p}<0.001\right)$ and asking children about their school experiences (McFadden's $\mathrm{R}^{2}=0.23, \mathrm{p}<0.001$ ).

Educational status: Father's and mother's level of education (Model 2) explains significantly more variance than the control variables. Especially for child-rearing behaviors requiring parents' education such as rhyming or telling stories (McFadden's $\mathrm{R}^{2}=0.33, \mathrm{p}<0.001$ ), and managing child's time (McFadden's $\left.\mathrm{R}^{2}=0.28, \mathrm{p}<0.001\right)$ we find a higher explained variance.

Social status: Model 3 explains significantly more variance than Model 0. However, by comparing Model 2 and 3, one can assert that social status does not explicate additional variance compared to educational status.

Full model of socio-economic status: As expected, the combination of economic, social, and human capital (Model 4) predicts the highest amount of variance in all our dependent variables, as between $27 \%$ and $35 \%$ of the variance in the child-rearing behavior can be explained by combining economic, educational, and social status as independent variables (see Table 6).

Differential effects of socioeconomic status on child-rearing behavior: Two different patterns occurred concerning the variation of the explained variance in the dependent variables. Figure 1 shows a similar pattern of variation in managing child's time and playing with the child. These two behaviors do not differ much depending on parents' SES. However, for each of the components of SES, managing time shows slightly higher variation based on SES compared to play. Figure 2, on the other hand, shows a similar pattern of variation in the other three parental behaviors depending on parents' SES, with telling rhymes carrying the highest variance. Among components of SES, educational status (Model 2) represents the highest variances.

Direction of the relations between SES and childrearing behavior: To explore the effect size and direction of each of the SES components, we present the coefficients from the logistic regressions estimating Model 4. For the estimation of SES on each of the dependent variables see Table 6. Economic status seems important for parenting and monthly household expenditure had a very small, but statisti-

\begin{tabular}{|l|c|c|c|c|c|}
\hline & & Econ. Status & Edu. Status & Social Status & $\begin{array}{c}\text { Econ. + } \\
\text { Edu. + } \\
\text { Social }\end{array}$ \\
\hline & Model 0 & Model 1 & Model 2 & Model 3 & Model 4 \\
\hline play & 0.15 & $0.19^{* * *}$ & $0.18^{* * *}$ & $0.22^{* * *}$ & $0.27^{* * *}$ \\
\hline rhyme & 0.25 & $0.30^{* * *}$ & $0.33^{* * *}$ & $0.26^{* * *}$ & 0.35 \\
\hline ask children & 0.20 & $0.23^{* * *}$ & $0.29^{* * *}$ & $0.23^{* * *}$ & $0.32^{* * *}$ \\
\hline manage time & 0.27 & $0.28^{* * *}$ & $0.30^{* * *}$ & $0.28^{* * *}$ & $0.32^{* *}$ \\
\hline supervise & 0.15 & $0.19^{* * *}$ & $0.25^{* * *}$ & 0.16 & 0.27 \\
\hline
\end{tabular}

Note: McFadden's $\mathrm{R}^{2},{ }^{*}$ show significant changes in McFadden's $\mathrm{R}^{2}$ between Model 0 and the respective Models. ${ }^{*} \mathrm{p}<.05,{ }^{* *} \mathrm{p}<.01,{ }^{* * *} \mathrm{p}<.001$

Tab. 5: Explained Variance in Logistic Regression Models, Source: Own presentation 


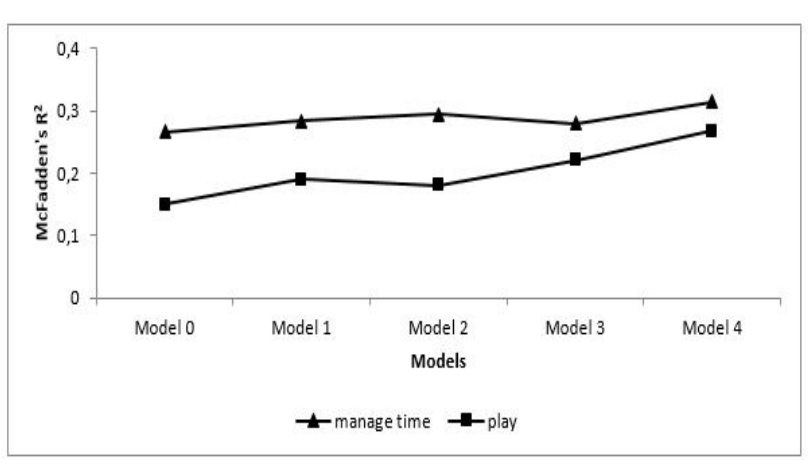

Fig. 1: Variance of child-rearing behavior \& different aspects of SES, Source: Own presentation

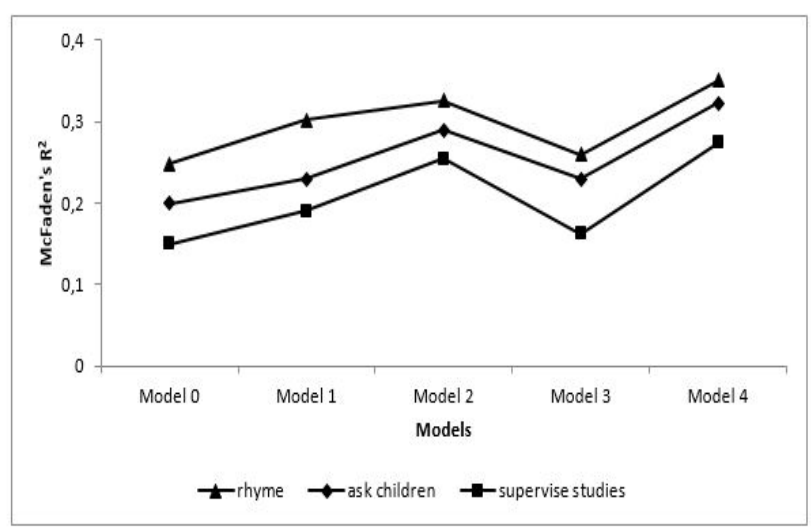

Fig. 2: Variance of child-rearing behavior \& different aspects of SES, Source: Own presentation

cally significant positive effect on the probability of involving in those practices, except for asking children about their daily experiences and supervising their study. One possible reason could be parents' involvement and effort in securing their financial status may lead to working for a longer time, which reduces their time spent with children or looking after their studies on a regular basis. However, in this study, we controlled for parents daily working hours and there was no significant effect of that on the probability of parental behaviors. Therefore, an alternative explanation could be that these parents, with their higher income, may allow children to have private tutors who look after their literacy activities and therefore, parents don't personally supervise children's study.

Parents' educational status seems to have a moderately stronger positive effect particularly on the last three practices. Practices such as helping children with their studies and asking them about school experiences, etc. need some educational foundation of parents, and thus, relatively more educated parents were more likely to help children with that. Moreover, mother's educational status has a relatively greater and consistent impact on the probability of managing children's time. Mothers with relatively higher level of education were significantly more likely to practice each of these parental practices in comparison to mothers only with primary education or no education. This may be because, given the patriarchal structure of Indian society, child-rearing responsibilities lay mostly on female family members and they have more interaction with children compared to male family members. Besides, parents' social status, measured in terms of parents' occupation, shows a weak association with parenting practices. This could be due to parents' involvement in their children's upbringing irrespective of their occupational status. On the contrary, it could also be that occupational status is not a suitable proxy for parents' social status in this context, and there are some other factors such as religion-and caste-based social stratification or other unobserved variables which can explain variation in social status better than parents' occupation did. In fact, evidence from our study advocates for a relatively stronger association between parents' religion and their caste origin and child-rearing behavior (see Appendix $3^{1}$ ).

Among other factors affecting child-rearing behavior (see Appendix 3), the number of children had a significant negative effect on the probability of practicing most of the behaviors in this study. This may be because a greater number of children implies less attention towards each of them. Parents, especially mothers, may find it difficult to equally take care of each of the children, and in that case, some of them (especially the older ones) are left to themselves. Even after controlling for SES-related differences, parents from Howrah district were found significantly more likely to practice some of the behaviors compared to parents from Murshidabad district. This may be due to some other cultural variation or any other reasons which was beyond the capacity of this study.

It is evident from the findings that there was variation in parents' child-rearing behavior depending on their SES, and the variation was two prongs. Firstly, each of the parenting practices measured in this study gets affected differently by SES. Secondly, each of the components of SES affects each of these child-rearing practices differently. On one hand, some of the child-rearing behaviors were found to have less variability based on SES, whereas some other behaviors vary more rapidly. On the other hand, among different aspects of SES, educational status has a relatively stronger effect on most of the child-rearing behaviors.

The association between SES and different parental behaviors may also depend on the type of behavior considered. Whether a parental practice varies depending on SES (and for which component of SES) depends on the nature of the practice. For example, whether it is demanding more time and attention from parents or demanding greater knowledge and aptitude may decide which of the components of SES will have relatively stronger (or weaker) effects on the variability of such parental practice considered. In addition, SES is a multi-dimensional construct and depends heavily on the context. Therefore, results may vary considerably depending on how SES is defined.

\section{Conclusion}

A considerable share of the variation in parental child-rearing behavior in developing countries can be explained by the variation in parents' SES. However, the nature and pattern of these variations may differ across countries based on their context. As child-rearing norms and practices are embedded in the culture, the set of child-rearing behavior may also vary depending on the country in consideration. Especially in a country like India where children are usually taken care of within the extended family, social and cultural values and norms are of greater importance. 


\begin{tabular}{|c|c|c|c|c|c|}
\hline \multirow[b]{2}{*}{ Independent Variables } & \multicolumn{5}{|c|}{ Dependent Variables } \\
\hline & Play & Manage time & Rhyme & $\begin{array}{c}\text { Ask } \\
\text { Children }\end{array}$ & $\begin{array}{l}\text { Supervise } \\
\text { Study }\end{array}$ \\
\hline \multirow[t]{2}{*}{ Log (Household Exp.) } & $0.053^{*}$ & $0.080^{* *}$ & $0.080^{* *}$ & -0.007 & $-0.086^{* *}$ \\
\hline & $(0.021)$ & $(0.030)$ & $(0.031)$ & $(0.031)$ & $(0.028)$ \\
\hline \multicolumn{6}{|l|}{$\begin{array}{l}\text { House Type } \\
\text { (Ref: Non-concrete) }\end{array}$} \\
\hline \multirow[t]{2}{*}{ Concrete } & 0.018 & -0.013 & $0.088^{*}$ & $0.117^{* * *}$ & $0.124^{* * *}$ \\
\hline & $(0.021)$ & $(0.033)$ & $(0.034)$ & $(0.034)$ & $(0.031)$ \\
\hline \multirow[t]{2}{*}{ Semi Concrete } & -0.008 & 0.040 & -0.023 & 0.036 & $0.060^{*}$ \\
\hline & $(0.018)$ & $(0.028)$ & $(0.028)$ & $(0.027)$ & $(0.024)$ \\
\hline \multicolumn{6}{|l|}{$\begin{array}{l}\text { House Ownership } \\
\text { (Ref: Rented) }\end{array}$} \\
\hline \multirow[t]{2}{*}{ Owned } & 0.057 & $0.139^{* * *}$ & -0.053 & -0.020 & 0.036 \\
\hline & $(0.033)$ & $(0.042)$ & $(0.041)$ & $(0.039)$ & $(0.037)$ \\
\hline \multicolumn{6}{|l|}{$\begin{array}{l}\text { Father's Education } \\
\text { (Ref: up to Primary) }\end{array}$} \\
\hline \multirow[t]{2}{*}{ Secondary } & 0.018 & 0.030 & 0.047 & $0.123^{* * *}$ & $0.087^{* * *}$ \\
\hline & $(0.019)$ & $(0.029)$ & $(0.028)$ & $(0.028)$ & $(0.024)$ \\
\hline \multirow[t]{2}{*}{ Higher Secondary or above } & $0.056^{*}$ & $0.109^{*}$ & $0.144^{*}$ & 0.017 & 0.045 \\
\hline & $(0.026)$ & $(0.054)$ & $(0.063)$ & $(0.061)$ & $(0.059)$ \\
\hline \multicolumn{6}{|l|}{$\begin{array}{l}\text { Mother's Education } \\
\text { (Ref: up to Primary) }\end{array}$} \\
\hline \multirow[t]{2}{*}{ Secondary } & 0.031 & $0.116^{* * *}$ & $0.153^{* * *}$ & $0.158^{* * *}$ & $0.156^{* * *}$ \\
\hline & $(0.018)$ & $(0.029)$ & $(0.030)$ & $(0.029)$ & $(0.025)$ \\
\hline \multirow[t]{2}{*}{ Higher Secondary or above } & 0.007 & 0.099 & $0.308^{* * *}$ & $0.278^{* * *}$ & $0.160^{* * *}$ \\
\hline & $(0.042)$ & $(0.054)$ & $(0.069)$ & $(0.053)$ & $(0.047)$ \\
\hline \multicolumn{6}{|l|}{$\begin{array}{l}\text { Father's Occupation Status } \\
\text { (Ref: Not employed) }\end{array}$} \\
\hline \multirow[t]{2}{*}{ Self-emp. } & 0.000 & -0.172 & 0.131 & -0.119 & 0.000 \\
\hline & $()$. & $(0.203)$ & $(0.158)$ & $(0.141)$ & (.) \\
\hline \multirow[t]{2}{*}{ Regular Emp. } & 0.000 & -0.127 & 0.105 & -0.254 & 0.000 \\
\hline & (.) & $(0.200)$ & $(0.155)$ & $(0.137)$ & (.) \\
\hline \multirow[t]{2}{*}{ Casual Emp. } & 0.000 & -0.210 & 0.126 & -0.101 & 0.000 \\
\hline & (.) & $(0.200)$ & $(0.154)$ & $(0.136)$ & (.) \\
\hline \multicolumn{6}{|l|}{$\begin{array}{l}\text { Mother's Occupation Status } \\
\text { (Ref: Not employed) }\end{array}$} \\
\hline \multirow[t]{2}{*}{ Self-emp. } & 0.000 & -0.011 & 0.232 & -0.112 & 0.011 \\
\hline & $()$. & $(0.222)$ & $(0.222)$ & $(0.216)$ & $(0.155)$ \\
\hline \multirow[t]{2}{*}{ Regular Emp. } & $-0.532^{*}$ & -0.135 & -0.092 & -0.182 & -0.071 \\
\hline & $(0.244)$ & $(0.153)$ & $(0.160)$ & $(0.164)$ & $(0.142)$ \\
\hline \multirow[t]{2}{*}{ Casual Emp. } & -0.257 & $-0.213^{*}$ & -0.083 & -0.099 & -0.078 \\
\hline & $(0.157)$ & $(0.099)$ & $(0.119)$ & $(0.117)$ & $(0.099)$ \\
\hline $\mathrm{N}$ & 1331 & 1355 & 1355 & 1355 & 1348 \\
\hline
\end{tabular}

Note: Coefficients represent the marginal effect S.E. in parentheses. ${ }^{*} \mathrm{p}<0.05,{ }^{* *} \mathrm{p}<0.01,{ }^{* * *} \mathrm{p}<0.001$. See Appendix $2^{1}$ for coefficients of control variables 
For the context of India, the study found strong evidence that parents' SES plays an important role in the type of care and interaction children receive at home. In addition, it also shows that the association between SES and child-rearing practices is multi-dimensional and varies depending on the type of practice considered and also on components of SES. This is in line with the expectations that can be raised from the literature. While the association between parents' education (as one key component of SES) and child-rearing practices was stronger, it was weaker for the other components such as economic and social status. The reason behind these variations could be due to the type of practices considered and also how SES is defined. It is already witnessed that parenting style (authoritative or authoritarian), the type and degree of interaction with children may also vary considerably based on parent's education (Glasgow, et al., 1997; Hoff-Ginsberg, 1998).

Therefore, parents' education seems to play a crucial role in child-rearing in India. This is mainly because educated parents can positively influence the upbringing of their children in many ways: by having a greater aspiration to provide a good foundation to their children, more information on child development, possible educational options for children, and also ability to directly helping children with their daily life. Given the fact that in the Indian context mothers are the primary caregivers, the study particularly advocates for the importance of education, especially for female education in a developing country context. It is clearly depicted that mother's education can play a significant part in child development by transmit their knowledge towards better child-rearing practices. Universalizing education in developing countries such as India may, thus, help to transmit the human capital from parents to children through different child-rearing behaviors as children's upbringing has a long term effect on their later development outcomes.

\section{Note}

1 For the appendixes see the website https://www.waxmann.com

\section{References}

Atkinson, A. M. (1994). Rural and urban families' use of child care. Family Relations, 43(1), 16-22. https://doi.org/10.2307/585137

Bradley, R. H. \& Corwyn, R. (1999). Parenting. In L. Balter \& C. Tamis-LeMonda(eds.), Child Psychology: A Handbook of Contemporary Issues (p. 339-362). Philadelphia, Pa: Psychology Press.

Bradley, R. H. (2002). Environment and Parenting. In M. H. Bornstein (ed.), Handbook of Parenting. Vol. 2 (p.281-314). Mahwah NJ: Lawrence Erlbaum.

Budwig, N. \& Chaudhary, N. (1996). Hindi-speaking caregivers' input: Towards an integration of typological and language socialization approaches. In A. Stringfellow, D. Cahana-Amitay, E. Hughes, \& A. Zukowski (eds.), Proceedings of the 20th annual Boston University conference on language development (p.135-145). Somerville, MA: Cascadilla.

Chaudhary, N. (2013). Parents' beliefs, socialisation practices and children's development in Indian families. Unpublished report of major research project for the University Grants Commission, New Delhi.

Darling, N. \& Steinberg, L. (1993). Parenting style as context: An integrative model. Psychological Bulletin, 113(3), 487-496. https://doi.org/10.1037/0033-2909.113.3. 487
El Nokali, N. E., Bachman, H. J. \& Votruba-Drzal, E. (2010). Parent Involvement and Children's Academic and Social Development in Elementary School. Child Development, 81(3), 988-1005. https://doi.org/10.2307/1131675

Feinstein, L. \& Duckworth, K. (2006). Development in The Early Years: Its Importance for School Performance and Adult Outcomes. Centre for Research on the Wider Benefits of Learning.

Feiring, C. \& Lewis, M. (1981). Middle-class differences in mother-child-interaction and the child's cognitive development. In T. M. Field, A. M. Sostek, P. Vietze \& P. H. Leiderman (eds.), Culture and early interactions (p. 63-91). Hillsdale, NJ: Lawrence Erlbaum.

Glasgow, K. L., Dornbusch, S. M., Troyer, L. \& Steinberg, L. (1997). Parenting styles, adolescents' attributions, and educational outcomes in nine heterogeneous high schools. Child Development, 68(3), 507-529.

Gutman, L. \& Feinstein, L. (2007). Parenting behaviors and children's development from infancy to early childhood: changes, continuities, and contributions. Research report No. 22. London: Centre for Research on the Wider Benefits of Learning.

Hart, B. \& Risley, T. R. (1995). Meaningful differences in the everyday experience of young American children. Baltimore: Brookes.

Hoff, E., Brett, L. \& Tardif, T. (2002). Socioeconomic Status and Parenting. In M. H. Bornstein (ed.), Handbook of Parenting. Vol. 2 (p. 231-252). Mahwah NJ: Lawrence Erlbaum.

Hoff-Ginsberg, E. (1998). The relation of birth order and socioeconomic status to children's language experience and language development. Applied Psycholinguistics, 19(4), 603-630. https://doi.org/10.1017/S0142716400010389

Hoff-Ginsberg, E. \& Tardif, T. (1995). Socioeconomic status and parenting. In M. H. Bornstein (ed.), Handbook of Parenting. Vol. 2 (p. 161-188). Mahwah NJ: Lawrence Erlbaum.

Jonsson, J. O. \& Erikson, R. (2000). Understanding Educational Inequality: The Swedish Experience. LAnnee sociologique (1940/1948). Troisieme serie, 50(2), 345-382. Presses Universitaires de France.

Mueller, C. \& Parcel, T. L. (1981). Measures of socioeconomic status: Alternatives and recommendations. Child Development, 52(1), 13-30. https://doi.org/10.2307 $/ 1129211$

Sénéchal, M. \& LeFevre, J. (2002). Parental Involvement in the Development of Children's Reading Skill: A Five-Year Longitudinal Study. Child Development, 73(2), 445-460. https://doi.org/10.1111/1467-8624.00417

Sigel, I. E. \& McGillicuddy-De Lisi, V. (2002). Parental Beliefs Are Cognitions: The Dynamic Belief Systems Model. In M. H. Bornstein (ed.), Handbook of Parenting. Vol. 3 (p. 485-508). Mahwah NJ: Lawrence Erlbaum.

Super, C. M. \& Harkness, S. (1986). The Developmental Niche: A Conceptualization at the Interface of Child and Culture. International Journal of Behavioral Development, 9(4), 545-569. https://doi.org/10.1177/016502548600900409

The Census of India (2011). 2011 Census Data. Access on 04.02.2020 http://censusindia.gov.in/2011-Common/CensusData2011.html

Tuli, M. (2013). Beliefs on Parenting and Childhood in India. Journal of Comparative Family Studies, 43(1), 81-91. https://doi.org/10.3138/jcfs.43.1.81

Woodworth, S., Belsky, J. \& Crnic, K. (1996). The determinants of fathering during the child's second and third years of life: A developmental analysis. Journal of Marriage and the Family, 58(3), 679-692. https://doi.org/10.2307/353728

\section{Saikat Ghosh}

is Research Associate, Ph.D. at the Leibniz Institute for Educational Trajectories (LIfBi). Previously he led the project titled "ECE India" (2019) funded by the German Research Foundation (DFG). His research lies in the domain of development economics with a particular focus on the economics of education and the developing world.

\section{Tobias Rausch}

completed his graduate studies with a degree in education and earned a Ph.D. in educational research from the University of Bamberg, Germany. He worked as a researcher at the University of Bamberg, focusing on teacher judgment accuracy and other topics of teacher education. 